\section{PERCEPTION OF CONSUMERS TOWARDS FAST FOOD EATING JOINTS: A STUDY IN JORHAT TOWN}

KEY WORDS: Fast food, Restaurants, consumers, perception

\title{
Barsha Borah
}

Assistant Professor CKB Commerce College, Jorhat, Assam India Pin- 784001

The changing life style and increasing disposable incomes had led to a tremendous growth of the restaurant industry. One of the restaurant formats attracting a larger section of consumers is the fast food eating joints or quick service restaurants. Fast food refers to the kind of food which can be quickly made and served in no time. One of the biggest merits of these restaurants is that it saves a lot of time thereby enabling the customer to get into multitasking. With the introduction of famous international franchises it has been noticed that consumers are day by day more inclining towards them. Consumers' choice of a particular restaurant depends on various factors like food quality, service quality, consistency in maintain quality and services, location, price, environment, parking facility and many more aspects. Therefore, consumer evaluation is very important to understand their attitude and the factors which determine their visit to the Fast Food Eating Joints. The present study is an attempt to understand the perception of consumers visiting the quick service restaurant in Jorhat town. The research also tried to highlight and study various factors which force the consumers to visit such eateries. For the fulfillment of the objectives of the study a well structured questionnaire is framed highlighting all possible factors which might influence a consumer visiting fast food eating joints. The structured questionnaire survey is done among 226 respondents and evaluation of the responses is done with the help of statistical tools and techniques.

\section{INTRODUCTION}

Today, service sector is the fastest growing sector in the world. It is important to pay special attention to the characteristics of the service sector and also to the customers' feelings that distinguish it from traditional manufacturing (Lee, 2009). As said by Shri Amitabh Kant, CEO, NITI Aayog, GOI, probably the rapid growth of Food Service Industry is due to India being the youngest country with internet and tech-savvy consumer base, having a high disposable income with little time to cook indoors. Now a day's everyone is in a hurry whether he is a young school going child or an office going person. Everyone tries to save time and effort due to which they are adopting the quicker version of everything and food is no exception to it. Due to the changing consumer choice for convenience, less effort and time saving, the food industry offers to its consumers the fast food. Bareham(1995) stated that the concept of fast food restaurants originated at USA in 1916 , and it is now dominating the world. Samuels (2000) has defined fast food by citing some examples of food such as pizza and tacos including snack food such as chips, cookies and pastries. Durrand (1992) has observed that the demand for fast food had shown and upward trend in France in the year 1991. Along with the other parts of the country and the world, fast food consumption in Jorhat, Assam is also gaining popularity at a very rapid pace. Previously fast food prepared by local restaurants such as momos, chowmein etc whose prices were also very reasonable and affordable were very popular among the customers. But after the introduction of international Quick Service Restaurants such as KFC, Pizza Hut, Dominos etc in the region, the whole scenario of consumer preference and consumer behaviour has changed. As the industry is growing and gaining popularity at a very rapid pace, the consumers' tastes, preferences, expectations, attitudes and behaviour is also changing at a very rapid pace. Taking into account the changing nature of food habits among the people, the study is carried out to find out the factors which directly and indirectly influences the people to visit the fast food restaurants in Jorhat town. The attitude formed towards a product or service influences the buying behavior of the consumer. According to Bender and Bender (1993) "fast food is a general term used for a limited menu of foods that lend themselves to production-line techniques; suppliers tend to specialize in products such as hamburgers, pizzas, chicken, or sandwiches". Ahmed, Hossain, Malek \& Begum (2008) argued that fast food consumption has become a trend among teenagers, youngsters and upper society. Fast food also plays crucial role in official and private meeting, working people at lunch time and also Tiffin of students. Park (2004) forwarded the view that visiting fast food restaurants not only gives satisfaction of hunger, convenience, pleasure, entertainment, time saving, social interaction ,mood transformation but it also provides consumers with excitement, pleasure and a sense of personal well-being . Richard and Padilla (2009) argued that consumer attitude towards fast food and restaurant selection is influenced by, nutritional profiles, vendor identity and the distance from a consumer's home. Turley \& Milliman (2000) were of the view that quality of food and physical environment of a restaurant are important determinants while selection a fast food restaurant. Clark and Wood (1998) gave stress on food quality and value for money as the most significant factors for restaurant selection. Carey and Genevieve (1995) in their study identified five factors as crucial for fast food restaurant selection and these are ranked as, (1) range of food; (2) quality of food; (3) price of food; (4) atmosphere; and (5) service speed. A study conducted by, Islam and Ullah (2010) in Bangladesh conclude that nearness and accessibility, similar taste of fast food, cost and quality relationship, discount and taste, cleanliness and hygiene, salesmanship and decoration, fat and cholesterol, and selfservice are some of the important factors influencing the consumption of fast foods. Tabassum \& Rahman (2012) concluded in their study on consumer preference towards fast food restaurants in Bangladesh that more and more urban dwellers prefer fast food for its nature of serving. Ragavan (1994) had stated that the driving forces for increased consumption of Fast food include the factors like convenience, easy accessibility, reasonable pricing, and adequate in quantity. Dani and Pabalkar (2013) found in their study that Fast food which provides the customer with a variety of options to choose from and has brought multiple manifolds in the Fast Food Industry. Indian cuisine is full of diversity and with different delicacy of food which is made easily available less than one roof in the Fast food restaurants.

\section{OBJECTIVES}

The study has been carried out keeping into account the following objectives:

1. To understand the perception of customers towards fast food eating joints in Jorhat town.

2. To identify the major determinants which influences the consumers' attitude towards the fast food eating joints.

\section{METHODOLOGY}

The research design adopted in the study is both descriptive as well as exploratory in nature. The entire analysis is based on primary data which were collected with the help of a 
structured questionnaire. Two stage sampling technique was adopted to collect the necessary information. The selection of sampling units had been done on random basis. Total sample size of the study is 226 .It has been found that on a daily basis approximately 2000 customers visited various international fast food restaurant located in various places of Jorhat. So the researcher tries to collect information from around 333 respondents as at $95 \%$ confidence limits the sample size can be specified by using the statistical formula $(n)=\frac{N}{1+N *(.05)^{2}}$.

Here by taking $N=2000$, the value of $n$ became 333 approximately. But due to the shortage of time and ignorance attitude of the respondents the study is restricted to a sample size of 226 only. The respondents in the study are divided into two categories i.e., frequent and non frequent visitors. Frequent visitors are those who visit IFR at least once in a week. On the other hand all other respondents are categorized as non frequent visitors. The questionnaire consists of both close ended as well as open-ended questions. The data collected were analyzed through cross tabulation, Kruskal Wallis test, Chi-Square test and T-test only as most of the variables in the present study are qualitative in nature. The entire analysis has been done with the help of SPSS software. In the present study FFR/ Quick service restaurants/fast food eating joints means the same.

\section{HYPOTHESIS}

$\mathbf{H}_{001}$ : There is no significant difference between customers' perception towards the quality of services at FFR.

$\mathbf{H}_{101}$ : There is significant difference between customers' perception towards the quality of services at of FFR.

$\mathbf{H}_{002}$ : There is no significant difference in customers' perception towards the quality of food provided at FFR.

$\mathbf{H}_{102}$ : There is significant difference in customers' perception towards the quality of food provided at FFR.

$\mathbf{H}_{003}$ : There is no significant difference in customers' perception towards consistency of various foods provided at IFR.

$\mathbf{H}_{103}$ : There is significant difference in customers' perception towards consistency of various foods provided at IFR.

$\mathbf{H}_{004}$ : There is no significant difference in customers' perception towards inclusion of food items at FFR closer to the cultural diet.

$\mathbf{H}_{104}$ : There is significant difference in customers' perception towards inclusion of food items at FFR closer to the cultural diet.

$\mathbf{H}_{005}$ : There is no significant difference in customers' perception towards inclusion of local specialty

$\mathbf{H}_{105}$ : There is significant difference in customers' perception towards inclusion of local specialty

$\mathbf{H}_{006}$ : There is no significant difference in customers' perception towards an atmosphere that reflects the local culture.

$\mathbf{H}_{106}$ : There is significant difference in customers' perception towards an atmosphere that reflects the local culture.

$\mathbf{H}_{007}$ : There is no significant difference in customers' perception towards the importance of international atmosphere and image of IFR.

$\mathbf{H}_{107}$ : There is significant difference in customers' perception towards the importance of international atmosphere and image of IFR.
$\mathbf{H}_{008}$ : There is no significant difference in customers' perception regarding the experience of same worldwide atmosphere.

$\mathbf{H}_{108}$ : There is significant difference in customers' perception regarding the experience of same worldwide atmosphere.

$\mathbf{H}_{009}$ : There is no significant difference in customers' perception towards trying something different than traditional food at IFR.

$\mathbf{H}_{109}$ : There is significant difference in customers' perception towards trying something different than traditional food at IFR.

$\mathbf{H}_{010}$ : There is no significant difference in perception of frequently visited customers' at IFR regarding various parameters viz., no of IFR visited, location, quality of food, variety in menu option, value for money, brand name, parking facility, quality of service, acceptance of plastic money, promotional offer, size order/appetizer, quality of packaging, friendliness of sales person, review of friend circle, depends on mood, travel further to eat at IFR, and pay more to eat at IFR.

$\mathbf{H}_{110}$ : There is significant difference in perception of frequently visited customers' at IFR regarding various parameters viz., no of IFR visited, location, quality of food, variety in menu option, value for money, brand name, parking facility, quality of service, acceptance of plastic money, promotional offer, size order/appetizer, quality of packaging, friendliness of sales person, review of friend circle, depends on mood, travel further to eat at IFR, and pay more to eat at IFR.

$\mathbf{H}_{011}$ : There is no significant difference in perception of not frequently visited customers' at IFR regarding various parameters viz., no of IFR visited, location, quality of food, variety in menu option, value for money, brand name, parking facility, quality of service, acceptance of plastic money, promotional offer, size order/appetizer, quality of packaging, friendliness of sales person, review of friend circle, depends on mood, travel further to eat at IFR, and pay more to eat at IFR.

$\mathbf{H}_{111}$ : There is significant difference in perception of not frequently visited customers' at IFR regarding various parameters viz., no of IFR visited, location, quality of food, variety in menu option, value for money, brand name, parking facility, quality of service, acceptance of plastic money, promotional offer, size order/appetizer, quality of packaging, friendliness of sales person, review of friend circle, depends on mood, travel further to eat at IFR, and pay more to eat at IFR.

\section{ANALYSIS AND INTERPRETATION} TABLE NO.1One-Sample Statistics

\begin{tabular}{|c|c|c|c|c|}
\hline & $\mathrm{N}$ & Mean & $\begin{array}{c}\text { Std. } \\
\text { Deviation }\end{array}$ & $\begin{array}{c}\text { Std. Error } \\
\text { Mean }\end{array}$ \\
\hline $\begin{array}{c}\text { Quality of services at } \\
\text { FFR very pleasant }\end{array}$ & 219 & 3.73 & .806 & .054 \\
\hline $\begin{array}{c}\text { Quality of food at FFR } \\
\text { very good }\end{array}$ & 218 & 3.80 & .881 & .060 \\
\hline $\begin{array}{c}\text { Quality of food at IFR } \\
\text { very consistent }\end{array}$ & 218 & 3.72 & .754 & .051 \\
\hline $\begin{array}{c}\text { FFR should offer food } \\
\text { closer to my cultural } \\
\text { diet }\end{array}$ & 218 & 3.51 & .927 & .063 \\
\hline $\begin{array}{c}\text { Atmosphere at FFR } \\
\text { should reflect local } \\
\text { culture }\end{array}$ & 218 & 3.57 & .964 & .065 \\
\hline $\begin{array}{c}\text { International } \\
\text { atmosphere and } \\
\text { image of IFR is } \\
\text { important }\end{array}$ & 218 & 3.52 & .989 & .067 \\
\hline
\end{tabular}




\begin{tabular}{|c|c|c|c|c|}
\hline $\begin{array}{c}\text { Same worldwide } \\
\text { atmosphere is } \\
\text { experienced at IFR }\end{array}$ & 217 & 3.72 & .952 & .065 \\
\hline $\begin{array}{c}\text { Try out something } \\
\text { different than } \\
\text { Traditional food at } \\
\text { IFR }\end{array}$ & 216 & 3.98 & .920 & .063 \\
\hline
\end{tabular}

Source:Field Survey, Oct, 2020

One-Sample Test

\begin{tabular}{|c|c|c|c|c|c|c|}
\hline & \multicolumn{5}{|c|}{ Test Value = 3.5 } \\
\cline { 2 - 6 } & $\mathrm{t}$ & $\mathrm{df}$ & $\begin{array}{c}\text { Sig. } \\
(2- \\
\text { tailed) }\end{array}$ & $\begin{array}{c}\text { Mean } \\
\text { Difference }\end{array}$ & $\begin{array}{c}95 \% \text { Confidence } \\
\text { Interval of the } \\
\text { Difference }\end{array}$ \\
\cline { 2 - 6 } & & & & & Lower & Upper \\
\hline $\begin{array}{c}\text { Quality of } \\
\text { services at } \\
\text { FFR very } \\
\text { pleasant }\end{array}$ & 4.151 & 218 & .000 & .226 & .12 & .33 \\
\hline $\begin{array}{c}\text { Quality of } \\
\text { food at FFR } \\
\text { very good }\end{array}$ & 5.072 & 217 & .000 & .303 & .19 & .42 \\
\hline $\begin{array}{c}\text { Quality of } \\
\text { food at IFR } \\
\text { very } \\
\text { consistent }\end{array}$ & 4.399 & 217 & .000 & .225 & .12 & .33 \\
\hline $\begin{array}{c}\text { FFR should } \\
\text { offer food } \\
\text { closer to my } \\
\text { cultural diet }\end{array}$ & .219 & 217 & .827 & .014 & -.11 & .14 \\
\hline $\begin{array}{c}\text { Atmosphere } \\
\text { at FFR } \\
\text { should } \\
\text { reflect local } \\
\text { culture }\end{array}$ & 1.054 & 217 & .293 & .069 & -.06 & .20 \\
\hline $\begin{array}{c}\text { International } \\
\text { atmosphere } \\
\text { and image of } \\
\text { IFR is } \\
\text { important }\end{array}$ & .274 & 217 & .784 & .018 & -.11 & .15 \\
\hline $\begin{array}{c}\text { Same } \\
\text { worldwide } \\
\text { atmosphere } \\
\text { is } \\
\text { experienced } \\
\text { at IFR }\end{array}$ & 3.386 & 216 & .001 & .219 & .09 & .35 \\
\hline $\begin{array}{c}\text { Try out } \\
\text { something } \\
\text { different } \\
\text { than } \\
\begin{array}{c}\text { Traditional } \\
\text { food at IFR }\end{array}\end{array}$ & 7.693 & 215 & .000 & .481 & .36 & .60 \\
\hline
\end{tabular}

Source: Field Survey, Oct, 2020

Here the researcher made an attempt to identify the effect of various factors that lead towards the positive perception of customers to visit FFR. For that one sample t- test was conducted that lead to the rejection of the null hypothesis $\mathrm{H}_{001}$, $\mathrm{H}_{002}, \mathrm{H}_{003}, \mathrm{H}_{008}, \mathrm{H}_{009}$ and null hypothesis $\mathrm{H}_{004}, \mathrm{H}_{005}, \mathrm{H}_{006}, \mathrm{H}_{007}$ were accepted. It implies that respondents were very much positive regarding the parameters viz., quality of services at FFR is very pleasant, quality of food at IFR is good and consistent, same worldwide atmosphere is experienced at IFR and try out something different than traditional food at FFR. While respondents have somewhat less positive perception towards the parameters viz., inclusion of cultural diet at FFR, reflection of culture in the atmosphere of IFR and importance of international atmosphere and image at IFR

TABLE NO. 5

\begin{tabular}{|c|c|c|c|c|c|}
\hline $\begin{array}{c}\text { frq_visi } \\
\text { torl }\end{array}$ & & $\bar{N}$ & Mean & \begin{tabular}{|c|} 
Std. \\
Deviation
\end{tabular} & $\begin{array}{c}\text { Std. } \\
\text { Error } \\
\text { Mean }\end{array}$ \\
\hline \multirow{15}{*}{$\begin{array}{l}\text { Not so } \\
\text { frequen } \\
\text { t visitor }\end{array}$} & Location of the IFR & 177 & 4.18 & .784 & .059 \\
\hline & \begin{tabular}{|c|} 
Quality of food at \\
IFR
\end{tabular} & 176 & 4.70 & .591 & \begin{tabular}{|l|l}
.045 \\
\end{tabular} \\
\hline & $\begin{array}{l}\text { Variety of menu } \\
\text { option }\end{array}$ & 174 & 4.20 & .663 & .050 \\
\hline & Value for money & 176 & 4.34 & .806 & .061 \\
\hline & \begin{tabular}{|l|} 
Brand Name of the \\
IFR
\end{tabular} & 173 & 3.84 & .905 & .069 \\
\hline & \begin{tabular}{|c|} 
Quality of Service \\
at IFR
\end{tabular} & 170 & 4.34 & .829 & .064 \\
\hline & Parking Facility & 172 & 3.73 & 1.015 & .077 \\
\hline & $\begin{array}{l}\text { Plastic card } \\
\text { Acceptance }\end{array}$ & 174 & 3.45 & 1.089 & \begin{tabular}{|l|}
.083 \\
\end{tabular} \\
\hline & $\begin{array}{l}\text { Adaptation of } \\
\text { Indian taste }\end{array}$ & 170 & 3.40 & .987 & \begin{tabular}{|c|}
.076 \\
\end{tabular} \\
\hline & Promotional Offers & 169 & 3.54 & .926 & .071 \\
\hline & \begin{tabular}{c|} 
Side \\
Orders/Appetizers \\
\end{tabular} & 163 & 3.41 & .961 & \begin{tabular}{|c|}
.075 \\
\end{tabular} \\
\hline & $\begin{array}{c}\text { Quality of } \\
\text { Packaging }\end{array}$ & 170 & 3.82 & .921 & .071 \\
\hline & $\begin{array}{l}\text { Friendliness of } \\
\text { Salesperson }\end{array}$ & 172 & 3.88 & .932 & \begin{tabular}{|c|}
.071 \\
\end{tabular} \\
\hline & $\begin{array}{l}\text { Review of friend } \\
\text { circle }\end{array}$ & 167 & 3.73 & .978 & .076 \\
\hline & $\begin{array}{l}\text { Depends on my } \\
\text { mood }\end{array}$ & 168 & 3.55 & 1.043 & .080 \\
\hline \multirow{15}{*}{$\begin{array}{c}\text { Freque } \\
\text { nt } \\
\text { Visitor }\end{array}$} & Location of the IFR & 42 & 4.24 & .850 & .131 \\
\hline & \begin{tabular}{|c|} 
Quality of food at \\
IFR
\end{tabular} & 42 & 4.74 & .497 & .077 \\
\hline & $\begin{array}{l}\text { Variety of menu } \\
\text { option }\end{array}$ & 42 & 4.33 & .650 & .100 \\
\hline & Value for money & 42 & \begin{tabular}{|l|}
4.19 \\
\end{tabular} & .707 & \begin{tabular}{|l|}
.109 \\
\end{tabular} \\
\hline & $\begin{array}{c}\text { Brand Name of the } \\
\text { IFR }\end{array}$ & 41 & 3.63 & 1.067 & .167 \\
\hline & \begin{tabular}{|c|} 
Quality of Service \\
at IFR
\end{tabular} & 42 & 4.29 & .835 & .129 \\
\hline & Parking Facility & 42 & 3.62 & 1.081 & \begin{tabular}{|l|}
.167 \\
\end{tabular} \\
\hline & $\begin{array}{l}\text { Plastic card } \\
\text { Acceptance }\end{array}$ & 42 & 3.17 & 1.267 & .196 \\
\hline & $\begin{array}{l}\text { Adaptation of } \\
\text { Indian taste }\end{array}$ & 42 & 3.52 & 1.042 & .161 \\
\hline & Promotional Offers & 42 & 3.26 & 1.083 & .167 \\
\hline & \begin{tabular}{|c|} 
Side \\
Orders/Appetizers
\end{tabular} & 43 & 3.53 & 1.008 & .154 \\
\hline & $\begin{array}{l}\text { Quality of } \\
\text { Packaging }\end{array}$ & 43 & \begin{tabular}{|l|}
3.88 \\
\end{tabular} & .956 & .146 \\
\hline & $\begin{array}{c}\text { Friendliness of } \\
\text { Salesperson }\end{array}$ & 43 & 4.00 & .724 & .110 \\
\hline & $\begin{array}{l}\text { Review of friend } \\
\text { circle }\end{array}$ & 43 & 3.74 & .902 & .138 \\
\hline & $\begin{array}{l}\text { Depends on my } \\
\text { mood }\end{array}$ & 43 & 3.56 & 1.098 & .167 \\
\hline
\end{tabular}

\section{One-Sample Test}

\begin{tabular}{|c|c|c|c|c|c|c|c|}
\hline \multirow{3}{*}{\multicolumn{2}{|c|}{ frq_visitorl }} & \multicolumn{6}{|c|}{ Test Value $=3.5$} \\
\hline & & \multirow[t]{2}{*}{$t$} & \multirow[t]{2}{*}{$\mathrm{df}$} & \multirow{2}{*}{\begin{tabular}{|c|} 
Sig. \\
$(2-$ \\
tailed $)$
\end{tabular}} & \multirow{2}{*}{$\begin{array}{c}\text { Mean } \\
\text { Differe } \\
\text { nce }\end{array}$} & \multicolumn{2}{|c|}{$\begin{array}{c}95 \% \\
\text { Confiden }\end{array}$} \\
\hline & & & & & & $\begin{array}{c}\text { Low } \\
\text { er }\end{array}$ & $\begin{array}{l}\text { Upp } \\
\text { er }\end{array}$ \\
\hline $\begin{array}{l}\text { Not so } \\
\text { frequent } \\
\text { visitor }\end{array}$ & $\begin{array}{c}\text { Location of the } \\
\text { IFR }\end{array}$ & $\begin{array}{c}11.55 \\
1\end{array}$ & 176 & .000 & .681 & .56 & \begin{tabular}{|l|}
.80 \\
\end{tabular} \\
\hline
\end{tabular}




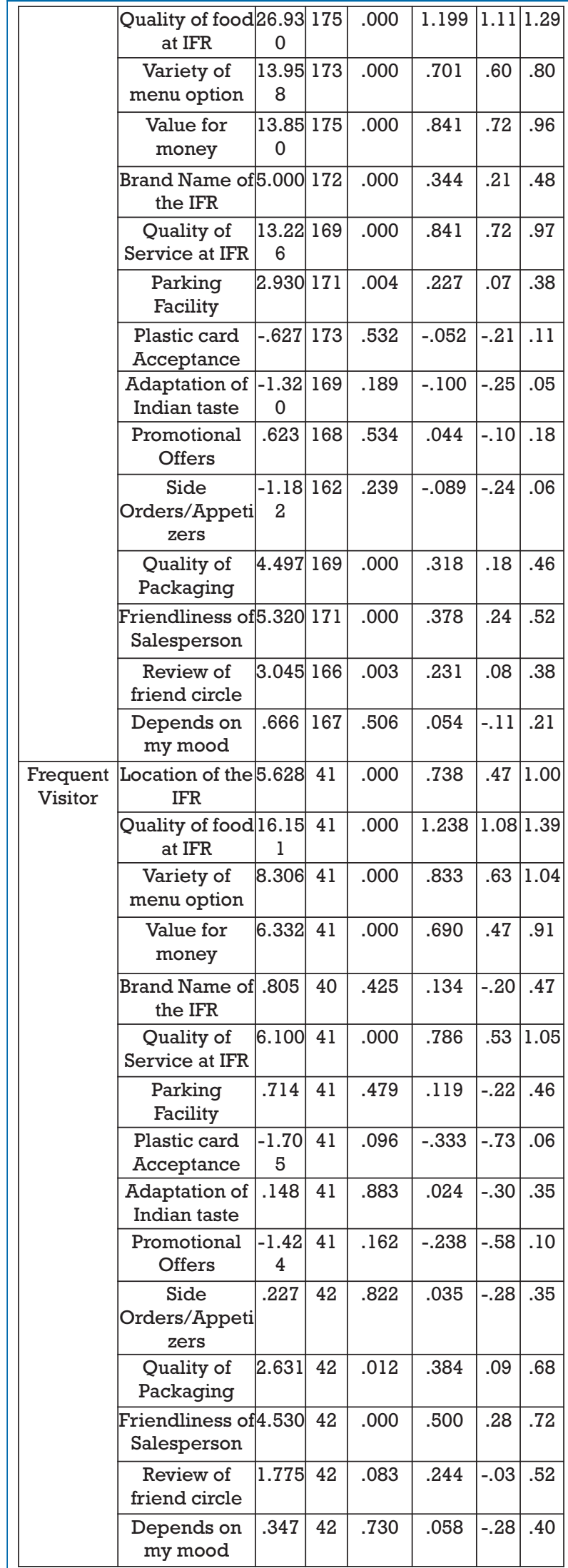

and in the above table an attempt has been made whether there exists any difference between the frequent visitors and not so frequent visitors at IFR. About the various factors that leads towards the positive perception to visit IFR. It is interesting to see that regarding the pleasant quality of services at IFR, the very good quality of food at IFR, and experience of same worldwide atmosphere at IFR, the view of frequent visitors and non frequent visitors were contradictory. In view of all other factors the perception of frequent visitors and not so frequent visitors does not differ very much. Working at the values, it can be inferred that not so frequent visitors are relatively more positive towards the quality of services, quality of food, and experience of the same worldwide atmosphere at IFR than the frequent visitors.

\section{CONCLUSION}

Fast food has become a part of our life. Most of the people specially the children and youngsters cannot do away with it. Jorhat is a developing town due to which many international brands are coming here along with local eateries. With other parts of the country the people here are also moving at a very fast pace due to which to save time they are finding alternatives which are easily affordable as well as consumable and food is the major aspect in this. With more disposable income in their hands people are more attracted towards the services of IFR. Many attributes affect the visitors towards the FFRs which have already been highlighted in the discussion. So, it can be concluded that the FFRs has been successful in knowing the factors which attract the customers in the city towards them and there is always room for improving their services to attract more and more customers.

\section{References}

1. Azam, MS (2005) Attitude model for study of customers'preference: Looking at Bangladesh's Life Insurance.Journal of the Institute of Business Studies, vol. 28,pp. 17-32.

2. Bender, AE \& Bender, DA (1993) A dictionary of food and nutrition, Oxford University Press, Oxford.

3. Ahmed, J, Hossain, ML, Malek, MA \& Begum, F( 2008). Assessment of Bacteriological Quality of Fast Foods and Soft Drinks in Relation to Safety and Hygiene. Bangladesh Journal of Microbiology, vol. 25, no. 1, pp. 73-75.

4. Bareham,J (1995). Consumer Behavior in the Food Industry. A European Perspective, Butterworth-Heinemann, Oxford.

5. Chawla Deepak and Soundi Neena, Research Methodology Concepts and Cases,Vikas Publishing House Pvt,Ltd,201 1.

6. Clark, M \& Wood, CR 1998, „, Consumer loyalty in the restaurant industry: A preliminary exploration of the issues ,International Journal of Contemporary Hospitality Management, vol. 10, no 4,pp. 139-144.

7. Carey, RA \& Genevieve, L 1995, ,USA snapshots: Factors influencing choice of sit-down restaurant ,USA Today, 23 June.

8. Dani Vinit, Pabalkar Vanishree (2013) Exploring of Consumer behavior towards fast food Industry: A Case study on Pune .Indian Journal of Applied Research.Vol:3, Issue:9.

9. Durrand (1992).Domestic Consumption Of Fast Food. Infos-Paris. 60:49-52.

10. George Darren and Mallery Paul, SPSS for Windows Step by Step, Pearson, 2011

11. Islam, $\mathrm{N} \&$ Ullah, $\mathrm{SGM}(2010)$. Factors Affecting Consumers Preferences On Fast Food Items In Bangladesh . The Journal of Applied Business Research, vol. 26, no. 4 .

12. Kothari C.R, Research Methodology,New Age Publishers,2008.

13. Park, C (2004). Efficient or enjoyable? Consumer values of eating-out and fast restaurant consumption in Korea. International Journal of Hospitality Management, vol.23,pp.87-94.

14. Richards, TJ \& Padilla, L (2009). Promotion and Fast Food Demand. American Journal of Agriculture and Economics, vol. 91, no. 1, pp. 168-183.

15. Samuels (2000). California High School Fast Food Survey February. 3900 Lake Shore Avenue Oakland CA 94610

16. Turley, LW \& Milliman, RE (2000). Atmospheric Effects on Shopping Behavior: A Review of the Experimental Evidence , Journal of Business Research, vol. 49, no.2,pp. 193-211.

17. Tabassum Ayesha and Rahman Tasnuva(2012) Differences in Consumer Attitude towards Selective Fast Food Restaurants in Bangladesh: An Implication of Multiattribute Attitude Model World Review of Business Research Vol.2.No.3.pp. 12-27

\section{Source:Field Survey, Oct, 2020}

Here the whole data set is divided into two mutually disjoint group viz., the group of frequent visitors at IFR and the group of not so very frequent visitors at IFR. The researchers found 45 frequent visitors against 181 not so very frequent visitors 